\title{
ANALYSIS OF URBAN PLANNING DOCUMENTS WITH THE USE OF DTM IN TERMS OF THEIR OPTIMIZATION TO IMPROVE AIR QUALITY
}

\author{
L. Kulesza ${ }^{1, *}$ \\ ${ }^{1}$ Faculty of Environmental, Geomatic and Energy Engineering, Kielce University of Technology, Poland - 1.kulesza@tu.kielce.pl
}

ICWG III/IVa

KEY WORDS: Urban Planning, Smog, Air Quality, DTM

\begin{abstract}
:
In recent years, the problem of air pollution in cities has significantly increased. According to the latest ranking published by the World Health Organization (WHO), there are 36 Polish urban centres among 50 European cities with the highest concentration of $\mathrm{PM}_{2.5}$ particulate matter. In order to improve the situation, corrective and preventive actions can be taken. The first of these mainly include the shift towards more ecological fuels and increasing the biologically active area. The second group includes, among others optimizing existing planning documents. From the point of view of the location of buildings, in particular industrial plants, the most favourable are the highest areas, where the dust generated as a result of fuel combustion can be dispersed much faster. Unfortunately, the applicable provisions of Polish law do not impose an obligation to include terrain elevation in spatial planning. The growing problem of smog has stimulated the analysis of planning documents for selected Polish cities from the list published by the WHO taking DTM into consideration. First of all, on the basis of DTM, three zones (unfavourable, advantageous and very favourable) were determined for each of the test areas from the point of view of the location of buildings. Then an index was established, which was called the Elevation Planning Potential that allows to determine whether and to what extent there are possibilities to make beneficial changes from the point of view of air quality in planning documents taking into account the terrain shape. It takes into consideration both information from DTM and data determined on the basis of urban planning documents covering the existing development and land-use as well as planned spatial development directions. The solutions developed can significantly improve the air quality in cities by optimizing the location of new buildings. In this paper the results are presented for the Żywiec commune.
\end{abstract}

\section{INTRODUCTION}

The problem of air pollution in cities is not a new subject, however, it is getting more and more serious every year. High concentration of various human activities is the reason for increasing the emission of various types of pollutants. Urban agglomerations are currently struggling with the problem of high concentrations of some chemical compounds e.g.: carbon monoxide, sulphur- and nitrogen oxides, some heavy metals and in some cases polycyclic aromatic hydrocarbons (Lim et al., 2005; Calori et al., 2006; Mediavilla-Sahagún, ApSimon, 2006; Oxley et al., 2009; Buchholz et al., 2013). As a result, the morbidity of asthma and other respiratory diseases increases. Especially dangerous to our respiratory tracts is particulate matter of a very small size (less than $2.5 \mu \mathrm{m}$ ), because it can easily get deep into lungs or even get into bloodstream (SierraVargas, Teran, 2012). The negative impact of individual chemical compounds on the quality of urban air depends on several individual factors such as: emission field characteristics, location, topography, meteorology, etc. The influence on the structure of pollutants, their spatial distribution and values have two main factors (Holnicki et al., 2017).

The first of these is related to the use of coal as fuel burned for heating used in residential sector. The reason for the increased emission of pollutants is usually low quality of the fuel burned, improper combustion, outdated or inefficient heating installations and lack of proper insulation of buildings. As a result into the atmosphere particulate matter pollution (especially $\mathrm{PM}_{2.5}$ ), $\mathrm{CO}, \mathrm{SO}_{\mathrm{X}}$, some heavy metals and $\mathrm{B}(\mathrm{a}) \mathrm{P}$ are released (Rogula-Kozłowska et. al., 2013). In particular, the latter is a big problem in Poland (EEA, 2018). World Health Organization (WHO) published a ranking, in which 36 out of 50 urban centres in Europe with the highest PM2.5 concentration are in Poland (WHO, 2016). One of the most polluted cities is the former capital of Poland - Cracow. This results from the overlap of a number of unfavourable conditions: topography (the city is located in the valley of the Vistula River), urban planning (closing of aeration channels impeding the exchange of air) or atmospheric (frequent occurrence of wind silence) (Jędruszkiewicz et al., 2016; MONIT-AIR, 2016). In order to improve the situation, it is necessary to implement a comprehensive strategy for the modernization of heating installations, in particular in residential single-family houses. The Polish Ministry of the Environment is currently promoting the "Clean Air" program, under which it is possible to obtain co-financing for building insulation, replacement of old windows or purchase of a low-emission heating boiler (Ministry of Environment, 2019). Another way for improvement is to strive to increase the percentage of biologically active area, for example by using green roofs (Saadatian et al., 2013; Hulicka, 2015).

The second factor is connected with the constantly growing number of motor vehicles on public roads. The increasing traffic has the largest share in total $\mathrm{NO}_{\mathrm{X}}$ emissions and a significant contribution to $\mathrm{Pb}, \mathrm{CO}, \mathrm{C}_{6} \mathrm{H}_{6}$ (EEA, 2018; Dimitriou, Kassomenos, 2014; Kiesewetter et al., 2014). As

* Corresponding author 
repair activities, it is possible to indicate the construction of intersections with circular traffic, modernization of public transport by introducing hybrid and electric buses, creating a network of interchange stations (Park \& Ride) or exclusion from the automotive traffic of individual parts of the city (Holnicki et al., 2017).

However, the above-mentioned actions aimed at reducing the amount of pollutants entering the atmosphere have a more corrective character than a preventive one. To prevent this phenomenon, solutions should be implemented already at the urban planning stage. Particular emphasis in recent years has been placed on creating new and securing existing aeration channels. For large urban agglomerations, they are of key importance in the process of ensuring proper air circulation (Michalik et al., 2017).

In general, the problem of air pollution mainly occurs in large urban centres, which has been already the subject of many studies (e.g. Calori et al., 2006; Mediavilla-Sahagún, ApSimon, 2006; Buchholz et al., 2013; Rogula-Kozłowska et. al., 2013; Jędruszkiewicz et al., 2016; MONIT-AIR, 2016; Holnicki et al., 2017). Unfortunately, this issue also applies to smaller towns located in mountainous areas. At nights with low horizontal pressure gradient a mountain breeze in the valley leads to accumulation of air pollution in the surface layer (Hertig, Wanner, 1984; Baumbach, Vogt, 1999; Lang et al., 2015; Chiliński et al. 2016). Topography of the area is the main factor affecting the movement of pollutants to higher troposphere levels (Carvalho et al., 2006). The concentration of pollutants diminishes considerably with increasing altitude above ground level. Survey made with measurement device attached to cable car wagons showed that higher values occur both at night and during the day (Zawadzka et al., 2017). This is related to the increase in wind speed as the altitude increases above ground level (MONIT-AIR, 2016). In effect the dust generated as a result of fuel combustion can be dispersed much faster. From the point of view of the location of buildings, in particular industrial plants, the most favourable are the higher areas.

\section{STUDY AREA}

The research area is located in Poland in the southern part of the Silesian province. Due to the fact that the analyzed planning document is adopted by the Commune Council, the research area must close within the administrative boundaries of the given unit. The analysis was carried out for the area of the City of Żywiec. According to the physico-geographical regionalization of Poland against the background of the division of Europe, this region is located in the Western Beskids macro region, which belong to the province of Western Carpathians. According to the aforementioned division, in the Western Beskids macro region one can distinguish among others: the Żywiecka Basin and the surrounding mountain ranges: from the south-east the Beskid Żywiecki, the Silesian Beskid from the west, the Beskid Mały from the north and the Beskid Średni from the east, also called Makowski (Żywiec, 2019). As you can see, the location of the city from the point of view of air pollution due to the surrounding mountain ranges is very unfavourable. Location of the study area in relation to Polish borders is shown in Figure 1.

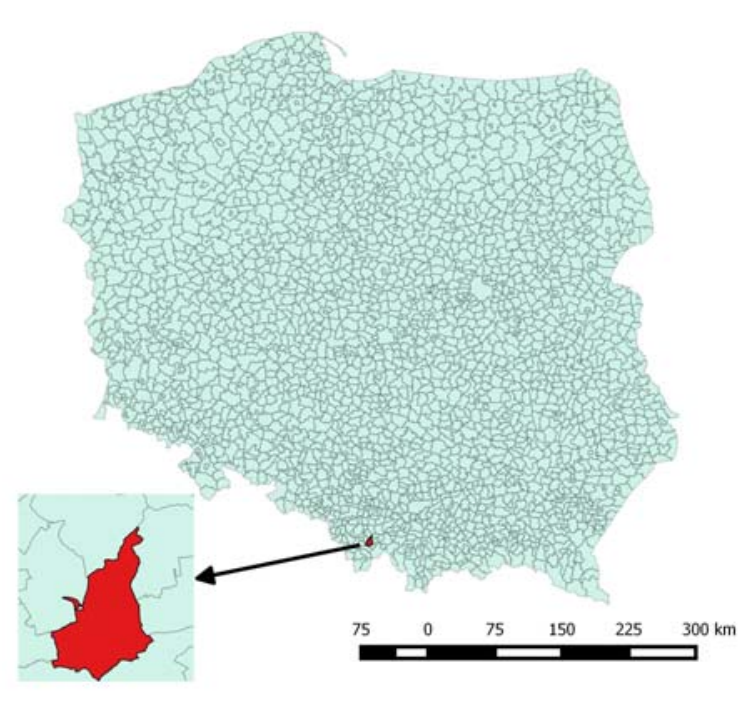

Figure 1. Location of the study area

\section{DATA}

The research was carried out on the basis of the Digital Terrain Model (DTM) available at the Main Office of Geodesy and Cartography web site and Planning Documents published on the public information bulletin of the Żywiec commune.

\subsection{Digital Terrain Model}

In the paper DTM in the form of GRID with a grid interval of $100 \mathrm{~m}$ was used. It is distributed free of charge by the Main Office of Geodesy and Cartography pursuant to art. 40a paragraph 2 of Act on Surveying and Cartographic Law (Act, 1989). Unfortunately, despite the fact that legal provisions introducing the obligation to publish data sets with a description in the form of metadata (the INSPIRE Directive) have been in force for some time, the materials on the website do not contain either information on the origin of data or their accuracy (GUGiK, 2019). However, taking into account the macro scale of the air pollution phenomenon, the use of generally available data is quite sufficient.

\subsection{Urban Planning Documents}

The research was based on the official, planning document called the Study of Conditions and Directions of Spatial Development (SCDSD) adopted by the City Council of Żywiec on 30 October 2014 (Żywiec, 2014). It describes the conditions for the city's development along with the spatial development directions and the justification of the adopted solutions. This document binds municipal authorities when adopting Local Spatial Development Plans (Act, 2003).

\section{METHODS}

Modelling the spread of air pollutants is a very complex issue. Over the years, many different prognostic models have been developed, but the choice of the right one for a specific case is crucial in order to properly estimate the propagation of pollutants (Leelossy et al. 2014). Another issue is the structure of the input data itself (emission, meteorological, topographic, physiographic) and the issue of their accuracy. They are a very important source of potential uncertainty of generated forecasts. 
An analytical description of the processes of pollution spread (transport, dispersion, deposition, physico-chemical changes) introduces an even wider range of uncertainty (Holnicki, 2011). With such complexity, modelling should be preceded by an expensive and long-lasting process of collecting the necessary data. For this reason, based on previous studies, a simplified approach has been proposed which can be successfully applied to any area.

As mentioned in introduction, the wind speed increases as the altitude increases above ground level. For a height of up to 10 meters above ground level, it is additionally limited by the presence of buildings and trees. In the wooded areas, the weakening of wind speed is not a big problem, because green areas affect the speed of deposition of pollutants emitted within them, limiting their negative effects. However, if the wind speed limit results from the presence of urban development, then in such areas an attempt should be made to significantly reduce emissions (MONIT-AIR, 2016). This paper proposes a method for assessing the potential of possible changes in existing planning documents. The aim was to develop a synthetic indicator enabling quantitative evaluation of results. The SCDSD of Żywiec City was analyzed. All spatial analyzes were performed in the QGIS software released under the GNU GPL license (QGIS, 2019). The research methodology consists of several successive stages.

\subsection{Determining zones based on DTM}

On the basis of DTM the research area has been divided into three zones: unfavourable (zone 1), advantageous (zone 2) and very favourable (zone 3 ). The first one includes the lowest located areas in a given commune. The limit value here is the average height calculated on the basis of the values of all individual grid cells of DTM. In the case of the second zone, the arithmetic mean is the limit value considering the minimum and maximum value of the height within a given area. The third zone is the area above this value.

\subsection{Analysis of planning documents}

Based on the SCDSD findings, areas designated for various types of housing have been defined: single-family and multifamily housing, service, hotel, guest house, production, storage and warehouse. The specified areas cover both existing and planned development. For this reason, they were reduced by invested and built-up areas, also established on the basis of SCDSD. Then, potential areas were defined, which purpose could be changed for development. Agricultural land was taken into account, including those with an indication for forestation due to the low soil quality class.

\subsection{Calculation of Elevation Planning Potential Index}

First, the surfaces of individual layers originating from SCDSD were determined, divided into zones created on the basis of DTM. Next Elevation Planning Potential Index was calculated. It is created by dividing the area of agricultural land included in the second and third zone through the surface of the designed development areas located in the first zone. It is determined by the formula (1). Its values are non-negative percentages. A value of $0 \%$ means that the planning documents can not be optimized. A value greater than $100 \%$ means that the area of high-land agricultural areas exceeds the area of low-lying areas designated for development.

$$
E P P I=\frac{A_{a_{-} 23}+A_{a f_{-} 23}}{A_{d_{-} 1}-A_{e_{-} 1}} * 100 \%
$$

where $\quad E P P I=$ Elevation Planning Potential Index

$\mathrm{A}_{\mathrm{a} \_23}=$ Area of arable land in zone 2 and 3

$\mathrm{A}_{\mathrm{af}-23}=$ Area of land for afforestation in zone 2 and 3

$A_{d_{-} 1}=$ Area intended for development in zone 1

$\mathrm{A}_{\mathrm{e} \_1}=$ Area of existing development in zone 1

\section{RESULTS}

Two threshold values separating individual zones have been calculated based on DTM. The first one is the average height within the research area determined on the basis of all grid cells. Its value was $400 \mathrm{~m}$ above sea level. The second one, 596 $\mathrm{m}$, is the average height calculated from the minimum $(338 \mathrm{~m})$ and maximum $(853 \mathrm{~m})$ altitude in a given municipality. The height range of each zone has been compared in Table 1. The zones are illustrated in Figure 2.

\begin{tabular}{|c|c|c|c|}
\hline Zone number & Zone description & $\mathrm{H}_{\min }[\mathrm{m}]$ & $\mathrm{H}_{\max }[\mathrm{m}]$ \\
\hline 1 & unfavourable & 338 & 400 \\
\hline 2 & advantageous & 400 & 596 \\
\hline 2 & very favourable & 596 & 853 \\
\hline
\end{tabular}

Table 1. Height range of zones

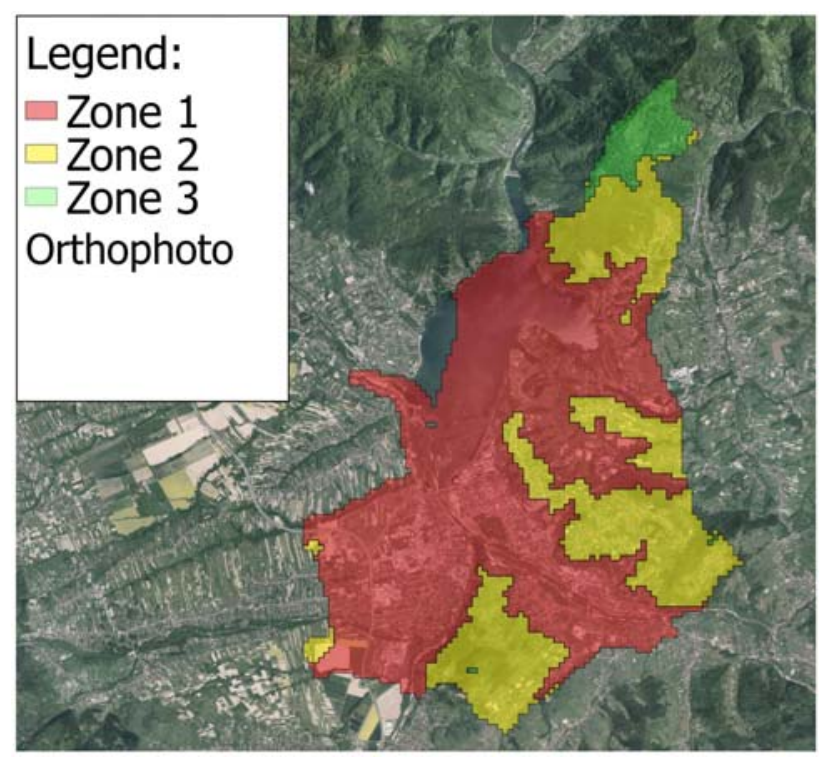

Figure 2. Zones derived from DTM

On the basis of SCDSD, the following layers have been specified: Existing Development, Intendent Development, Arable Land and Land for Afforestation. Next, the surfaces of each of them were determined in individual zones designated by DTM. The percentage of each zone in each layer is shown in Table 2 .

\begin{tabular}{|c|c|c|c|}
\hline Layer & Zone 1 & Zone 2 & Zone 3 \\
\hline Existing Development & $82.3 \%$ & $17.6 \%$ & $0.1 \%$ \\
\hline $\begin{array}{c}\text { Intendent Development } \\
\text { - Existing Delevopment }\end{array}$ & $78.2 \%$ & $21.8 \%$ & $0.0 \%$ \\
\hline Arable Land & $49.4 \%$ & $50.6 \%$ & $0.0 \%$ \\
\hline Land for Afforestation & $28.9 \%$ & $71.1 \%$ & $0.0 \%$ \\
\hline
\end{tabular}

Table 2. Distribution of layers in zones 
When analyzing the information included in Table 2, it can be seen that the majority of agricultural and intended for forestation land is located in the second zone $(50.6 \%$ and $71.1 \%$ respectively). The situation is different in the case of existing development. The major part of the layer is located in areas below the average height (zone 1). The situation is similar in the case of areas planned to be invested. The reason for this is locating buildings in the immediate vicinity of watercourses already at the stage of formation of individual human settlements. Rivers, due to the impact of gravity, always head towards the bottom of the valley. As the city develops, the buildings are located at an increasing distance from the watercourse. However, it may turn out that areas located at different altitudes may be at a similar distance. As mentioned in the introduction, the areas that are higher from the point of view of pollution dispersion are the most favourable. Urban planning goal is to maintain spatial order and set directions for the development of the commune. For this reason, it is important to consider the terrain shape at the stage of planning the development of a given town. Unfortunately, no such statutory obligation has been introduced in Polish law up to the present day. In order to try to improve the situation, first there is need to analyze existing planning documents to determine the scope of potential changes. The Elevation Planning Potential Index (EPPI) established in this paper allows to define the scope of potential changes. Using the formula (1) for the analyzed Żywiec commune, the EPPI was fixed at level $26.6 \%$. The conclusion is that the scope of potential changes in the analyzed planning documents is quite wide.

\section{CONCLUSIONS}

Empirical studies have shown that the wind force is proportional to the height above the ground level. In the ground zone it may be additionally limited by buildings and high vegetation (MONIT-AIR, 2016). Wind blowing is an important factor that contributes to the faster dispersion of air pollution generated by the combustion of fuels for heating purposes. As a result, there is a problem with smog occurring not only in large cities, but also in small towns located in mountainous areas (Zawadzka et al., 2017). The paper focused on the latter case and proposed a method for assessing existing planning documents from the point of view of introducing changes to improve dispersion of pollution. Unfortunately, the current provisions of Polish law do not impose an obligation to take into account terrain elevation in spatial planning (Act, 2003). As a result, $82.3 \%$ and $78.2 \%$ of the built-up areas and areas designated for development, respectively, are located in areas below the average height within the analyzed Żywiec commune. In order to obtain a quantitative evaluation of the results, a synthetic index was developed to identify the potential of potential changes in planning documents. It is called the Elevation Planning Potential Index and is calculated as the ratio of the agricultural and intended for forestation land found in advantageous and very favourable zones to built-up areas located in unfavourable zone. The obtained value of EPPI = $26.6 \%$ means that in the case of more than a quarter of the areas designated for the development, it is possible to select higher and therefore more favourable areas. In the case of the described study area, there are no agricultural areas or areas for afforestation located in zone 3 . However, in the case of their occurrence, they should be treated as a priority when creating a project of planning documents. The analyzes omit the economic aspect related to the soil classification and the costs of any compensation to landowners in connection with the change of planning documents. However, taking into account the potential benefits in the form of cleaner air within the city and reducing the costs of building a sanitary sewage system through limiting the construction of pumping stations, it can be assumed that they compensate to some degree.

\section{ACKNOWLEDGEMENTS}

The results have been developed in connection with the RID project (Regionalna Inicjatywa Doskonałości).

\section{REFERENCES}

Act of 17 May 1989 on Surveying and Cartographic Law. Journal of Laws of 2019, item 725, as amended

Act of 27 March 2003 on Planning and Spatial Development. Journal of Laws of 2018, item 1945, as amended.

Baumbach, G., Vogt U., 1999: Experimental determination of the effect of mountain-valley breeze circulation on air pollution in the vicinity of Freiburg. Atmospheric Environment, 33(24), 4019-4027.

Buchholz, S., Krein, A., Junk, J., Heinemann, G., Hoffmann, L., 2013: Simulation of urban-scale air pollution patterns in Luxembourg: contributing sources and emission scenarios. Environmental Modelling \& Assessment, 18, 271-283.

Calori, G., Clemente, M., De Maria, R., Finardi, S., Lollobrigida, F., Tinarelli, G., 2006: Air quality integrated modelling in Turin urban area. Environmental Modelling \& Software, 21, 468-476.

Carvalho, A.C., Carvalho, A., Gelpi, I., Barreiro, M., Borrego, C., Miranda, A.I., Perez-Munuzuri, V., 2006: Influence of topography and land use on pollutants dispersion in the Atlantic coast of Iberian Peninsula. Atmospheric Environment, 40, 39693982 .

Chiliński, M.T., Markowicz, K., Markowicz, J., 2016: Observation of vertical variability of black carbon concentration in lower troposphere on campaigns in Poland. Atmospheric Environment, 137.

Dimitriou, K., Kassomenos, P., 2014: A study on the reconstitution of daily PM10 and PM2.5 levels in Paris. Atmospheric Environment, 98, 648-654.

EEA, 2018. European Environment Agency. Air quality in Europe - Report No 12/2018. doi.org/10.2800/777411.

GUGiK, 2019. Main Office of Geodesy and Cartography. http://www.gugik.gov.pl/pzgik/dane-bez-oplat/dane-dotyczacenumerycznego-modelu-terenu-o-interwale-siatki-co-najmniej100-m-nmt_100 (12 July 2019).

Hertig, J.A, Wanner, H., 1984: Studies of Urban Climates and Air Pollution in Switzerland. Journal of Climatology \& Applied Meteorology During nights with low horizontal pressure gradient a mountain breeze in the valley leads to accumulation of air pollution in the surface layer, 23(12). 
Holnicki, P., 2011: Uncertainty in Integrated Modelling of Air Quality. Advanced Air Pollution, IntechOpen, ISBN: 978-953307-511-2.

Holnicki, P., Kałuszko, A., Nahorski, Z., Stankiewicz, K., Trapp, W., 2017: Air quality modeling for Warsaw agglomeration. Archives of Environmental Protection, 43(1), 48-64. doi.org/10.1515/aep-2017-0005.

Hulicka, A., 2015: Miasto zielone. Miasto zrównoważone. Sposoby kształtowania miejskich terenów zieleni w nawiązaniu do idei Green city (Green City. A sustainable city. Ways of shaping the Urban green space in relation to the idea of Green city). Prace Geograficzne, 141, 73-85.

Jędruszkiewicz, J., Piotrowski, P., Pietras, B., 2016: Koncentracja zanieczyszczeń pyłowych powietrza PM2,5 w Krakowie w latach 2010-2014 (Concentration of the air dust pollution PM2.5 in Cracow in 2010-2014). Acta Geographica Lodziensia, 104, 123-135.

Kiesewetter, G., Borken-Kleefeld, J., Schöpp, W., Heyes, C., Thunis, P., Bessagnet, B., Terrenoire, E., Amann, M., 2014: Modelling street level PM10 concentrations across Europe: source apportionment and possible futures. Atmospheric Chemistry and Physics Discussions, 14, 18315-18354.

Lang, M.N., Gohm, A., Wagner, J.S., 2015: The impact of embedded valleys on daytime pollution transport over a mountain range. Atmospheric Chemistry and Physics, 15(10), 14315-14356.

Leelossy, A., Molnar, F., Izsak, F., Havasi, A., Lagzi, I., Meszaros, R., 2014: Dispersion modeling of air pollutants in the atmosphere: a review. Central European Journal of Geosciences, 6(3), 257-278.

Lim, L.L., Hughes, S.J., Hellawell, E.E., 2005: Integrated decision support system for urban air quality assessment. Environmental Modelling \& Software, 20, 947-954.

Mediavilla-Sahagún, A., ApSimon, H.M., 2006: Urban scale integrated assessment for London: Which emission reduction strategies are more effective in attaining prescribed PM10 air quality standards by 2005? Environmental Modelling \& Software, 21, 501-513.

Michalik, A., Zwirowicz-Rutkowska, A., Wojtkiewicz, M., 2017: Problematyka przeciwdziałania zanieczyszczeniom powietrza $\mathrm{w}$ pracach projektowych urbanistów i architektów w kontekście wykorzystania infrastruktur i sytemów informacji przestrzennej (The issue of air pollution prevention in the work of the spatial planners and architects in the context of the use of spatial information infrastructures and systems). Acta Scientiarium Polonorum Administratio Locorum, 16(4), 263275.

Ministry of Environment, 2019. "Clean Air" Program. https://www.gov.pl/web/srodowisko/o-programie (12 July 2019).

MONIT-AIR, 2016: Atlas pokrycia terenu i przewietrzania Krakowa (Atlas of land cover and ventilation in Cracow). Urząd Miasta Krakowa (Cracow City Hall), ISBN 978-83918196-5-4
Oxley, T., Valiantis, M., Elshkaki, A., ApSimon, H.M., 2009: Background, Road and Urban Transport modeling of Air quality Limit values (The BRUTAL model). Environmental Modelling \& Software, 24, 1036-1050.

QGIS, 2019. QGIS Software, Version 3.8. https://qgis.org.

Rogula-Kozłowska, W., Kozielska , B., Klejnowski, K., Szopa, S., 2013: Hazardous compounds in urban PM in the central part of Upper Silesia (Poland) in Winter. Archives of Environmental Protection, 39, 53-65.

Saadatian, O., Sopian, K., Salleh, E., Lim, C.H., Riffat, S., Saadatian, E., Toudeshki, A., Sulaiman, M.Y., 2013: A review of energy aspects of green roofs. Renewable and Sustainable Energy Reviews, 23, 155-168.

Sierra-Vargas, M.P., Teran, L.M., 2012: Air pollution: Impact and prevention. Respirology, 17(7), 1031-1038.

WHO, 2016. World Health Organization, Air pollution levels rising in many of the world's poorest cities, https://www.who.int/news-room/detail/12-05-2016-airpollution-levels-rising-in-many-of-the-world-s-poorest-cities (12 July 2019).

Zawadzka, O., Posyniak, M., Kulesza, K., Markuszewski, P., Chiliński, M.T., Czyżewska, M., Lisok, J., Markowicz, K., 2017: Study of the vertical variability of aerosol properties based on cable cars in-situ measurements. Atmospheric Pollution Research, 8, 968-978.

Żywiec, 2014. Official public information bulletin of the Żywiec commune - urban planning documents. http://www.bip.zywiec.pl/index.php?modul=aktualnosci\&kat_i $\mathrm{d}=54 \& \mathrm{id}=3910$ (12 July 2019)

Żywiec, 2019. Official Web Site of Żywiec commune information on the location of the commune. http://www.zywiec.pl/polozenie,9 (12 July 2019). 